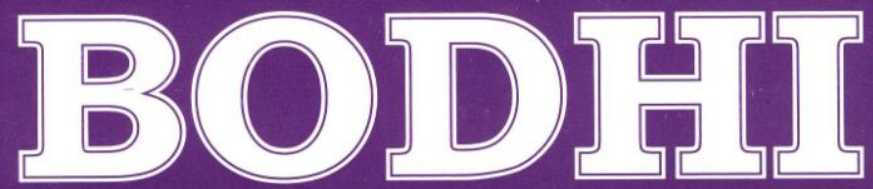

An Interdisciplinary Journal

ISSN: 2091-0479

Department of Languages and Mass Communication School of Arts

Kathmandu University

Bodhi, 4 (1), 161-167. ISSN 2091-0479. (C) 2010 Kathmandu University 


\section{Reflective journaling: An autoethnographic experience}

- Kashiraj Pandey

Reflective writing or what I rather call journaling empowers us to creatively express who we are as a portrayal of our personal experiences. By motivating ourselves to be honest and put our voices on paper, we cannot help but disrupt old patterns and beliefs. Anybody, who may be present or absent in any given context, is creative and it is all about whether or not we document our creativity that comes as a product of the interaction with the world around us which voluntarily boosts up confidence and cross cultural understanding for overall transformation.

The practice of journaling and the Department of Languages and Mass Communication

To me, writing perhaps works as craft while not worrying on the meaning as we prefer to leave readers to make their own meanings that anyway keep changing according to socialtemporal contexts. As response to our regular teaching learning activities, the teachers of English at the Department of Languages and Mass Communication are regularizing the practice of journaling with students since 2005. As a teacher and also the reflective practitioner, I step into each classroom once a week and facilitate the class, while students in turn, discuss around the subject matter. With my frequent moderation and facilitation, I could see that more learning is taking place than just teaching. According to the individual understanding, all students can reflect through writing in journal, the outcome. Maintaining a journal has prepared everyone realize creativity as a plant growing in newer and more beautiful interweave every day making ourselves fresh and anew. Thinking many 
might fail to follow this way while not getting conducive environment, we encourage the students explore their creativity that was seen in different levels in and outside the classroom. Based in our experience at Kathmandu University, as we start the semester with a set of instructions about using journals in the classroom, as Young (1999) suggests "that journals are valuable not just busy work, they are used daily as students and teacher build the knowledge of course" (p. 18), and we too design some steps as guidelines, and the rubrics for testing in the beginning of each semester-group students. They can be; first, to ask students buy a No. 3 Register. Secondly, to make them clear on the language of the journal, in our case it should be English as mentioned in the prescribed text book, "unless told otherwise, in this class we shall use only English, even in conversations among students before, during, and after class" (Lohani \& Nissani, 2008, p. 9 ). Thirdly, to monitor, facilitate, collect, and read the journal on a regular basis. Then, encouraging them to write about a wide variety of topics of their choice as free writing with a theme that has link to the text discussed in the class, we can ask students to leave a blank space between entries for room to comment later. This process holds significant place in learning through creating individual stories and poems when all the students write something during and after the class time. Finally, we can look for ways to share the journals between and among students. To ensure that the students understood the connection between the theory in the lectures (and readings), and the practice in real life; we do practice reflective journal writing in the classroom among assigning a series of questions each week to help students make connections between the lecture and the textbooks, and what learning really meant to them.

\section{Literature, life, reflective writing, and communication skills}

When the students are able to develop friendship with literary texts and make these texts part of their life and develop enthusiasm to decipher more and more texts from the works of imagination, their communication strength empowers and there 
meets the objectives of learning in the Communication Skills (ENGT) course for students of Media, Science, and Engineering. As students start to find meaning in the texts in relation to their lives, it strengthens their reading habit, "in order to develop as a writer, one must be a reader" (Colonna \& Gilbert, 2006, p. v), therefore helps them in vocabulary expansion, communication, production, presentation, and in overall level of understanding linking with background concept for writing, the reflective practice of journaling.

Even before one actually sits and writes, the most important thing I remember is that it makes us read and read, explore new worlds, new minds, and new avenues. In our case, English as language is used most effectively at its idiomatic best in literary texts as to enhance the students' competence in creativity thus leading to their overall transformation most effectively.

A good introduction to literature can compensate for the deficiencies of linguistic approach in the area of grammar, vocabulary and syntax that can enhance the students' competence in creativity. Writing provides the students abundant practice with examples of the subtle and complex uses of grammar and vocabulary of a language. We all perform pretty well and in almost the same way in our subject matter, more specifically in the particular area of Science and Engineering, but what makes us different is our better skills in communication, may it be verbal or non-verbal, thereby we hunt the job, and lead the market.

Everyone has some kind of gift. Being talented does not mean just being a good musician, writer or athlete. There are many kinds of talent. You may be a great conversationalist, or make friends easily, or be able to put others at ease. Or you may have a gift for telling jokes, selling things or living economically. You may be punctual, patient, reliable, kind or optimistic. Or you may love taking on new challenges, be strongly committed to helping others, or have an ability to bring 
them joy. Without doubt, you possess your special jewel, your own unique talent.

(Ikeda as cited in Kemp, 2008, p. 1)

We all have the capacities for growth, change, and adaptation, but we often lack opportunity for their expression. The underlying thrust of reflective writing as means of selfexploration is to gather the significant works that advocated in encouraging writers' creativity through journaling.

When I write, that willingly relieves me from all related tensions and gives me fresh air to think ahead. Journaling, the product of reflective writing has helped me and my students improve language skills once we together passed through all given scrupulous activities. I think writing releases a person from the problem. And when we make the problem universal, there remains nothing private as we expose it. I am inclined by Brenda Ueland (as cited in Richardson, 2005),

Writing, the creative effort, should come first - at least for some part of everyday of your life. It is a wonderful blessing if you will use it. You will become happier, more enlightened, alive, impassioned, light-hearted, and generous to everybody else. Even your health will improve. Colds will disappear and all the other ailments of discouragements and boredom. (p. 973)

I also think that writing takes one's pain away. "Writing is a certain way of wanting freedom: once you have begun, you are committed willy-nilly" (Sartre, 1992, p. 992). And, journaling is analyzing, reconsidering and questioning experiences within a given context through individual and collective reflection. For example, students in my classroom sometimes found that the realities of their practical experiences did not match with what they had already learned from theories in previous classes. With this proposition, I agree with Moon (1999, p. 4) that "the process of reflecting on the disparities between your expectations and actual experience enables you to become more engaged with the process of your learning". According to these scholars, reflective practice has strong ground for the overall 
development of the practitioners' creativity, confidence, and overall understanding; at some point of time in life, it works as a marker of success.

\section{My journey in reflective journaling}

"Journaling in its various forms is a means for recording personal thoughts, daily experiences, and evolving insights (Hiemstra, 2001, p. 20). This reflective process often evokes conversations with self and a real or even an imagined other person making the practitioners able to review or reread the earlier reflections with a progressive clarification of possible insights. Even with the sufficient use and attempts by the educators to encourage personal reflection in various ways, journaling still remains underused as a teaching or learning tool. My continuous effort to bolster creativity from the students' side where the teacher merely facilitates or just positively motivates students to think with different thoughts to explore and explore has brought more creative writers from various disciplines who are more interdisciplinary in fact.

Who does not want to be creative is the question now. However, one can only master the art of writing by "writing" creatively, not by "wanting to write", which always catapulted us ahead towards our goal of transformation. Creativity that brings us into being also gives us the cause to exist. Therefore, being creative means it is characterized by originality, expressiveness, and imaginative where the writers' focus would be to create environment for readers where they are likely to forget everything and travel along the path captured by the imagination of the authors.

For the past thirty year friendship with Literature, and during my seven year journey at the Kathmandu University discussing literary texts every semester, I along with my students have reached in such a state that I hardly find difference between myself (ourselves) and the authors. In the process of producing reflective understanding, I saw how the classroom became 
interactive time and again as the teaching and learning activity happened at the same time and product was seen in the form of individual journaling. Instead of one way, the learning happens in multiple levels, a differently depicted world produced by multiple discourses not only to deconstruct the accepted social categories, but also in believing multiple truths where our personal stories are set in cultural contexts.

When we write reflective journals, creativity, self confidence, cross-cultural understanding, and transformation are complimentary to one another because all the participants feel different every other moment. When practiced writing keenly with my students in an undergraduate classroom, I have found tremendous worth in the process of reflective writing. Analyzing the feedback I have taken from students at the end of every semester, the major objectives of reflective writing is fulfilled as I am able to capture the moments making all students write something creative through journaling.

\section{Conclusion}

As part of my own reflective journaling and along with the students, I have also created many stories, poems, and essays. As I reflect while comparing to the first day of this teachering career, I should confess I feel different now. I am different in the sense that because of reflection and integration, I have come to realize many defaults in my way of teaching, dealing, and evaluating the students that led me to make changes accordingly. I have gained confidence in making presentations in more effective ways applying the devices of communication skills. I have become more tolerant and respectful to the self and "other" cultural/ ideological differences. Moreover, this autoethnographic mode of inquiry led me to realize and reflect so much that my suppressed agonies, confusions, regrets, contempt, timidity, all got a platform to flourish into humility. Journaling, the product of reflective thinking has helped the students and me to improve our language skills once we passed through all (given) rigorous activities. Accordingly, I believe 
there are a number of potential benefits for learners in maintaining journal in a writing class. For example, students achieve enhanced intellectual growth and development especially as they gain more experience with the writing or recording procedures based on their lived experiences.

\section{References:}

Colonna, M. R., \& Gilbert, J. E. (2006). Reason to write. London: Oxford.

Hiemstra, R. (2001). Uses and benefits of journal writing. In L. M. English \& M. A. Gillen, (Eds.), Promoting journal writing in adult education (New Directions for Adult and Continuing Education, No. 90, pp. 19-26). San Francisco: Jossey-Bass.

Kemp, K. (2008). How have I come to recognise and develop my talents which are my gift to my colleagues and pupils? Retrieved February 12, 2011, from http://www.actionresearch.net/writings/tuesdayma/kkgt unit2008.htm

Lohani, S. \& Nissani, M. (Eds.). (2008). Flax golden tales. Kathmandu: Ekta.

Moon, J. (1999). Learning journals: A handbook for academics, students and professional development. London: Kogan.

Richardson, L. (2005). Writing: A method of inquiry. In N. K. Denzin \& Y. S. Lincoln (Eds.), The Sage handbook of qualitative research. London: Sage.

Sartre, J. P. (1992). Why write. In H. Adams (Ed.). Critical theory since Plato (Revised ed.). London: Harcourt Brace.

Young, A. (1999). Teaching writing across the curriculum $\left(3^{\text {rd }}\right.$ ed.). NJ: Prentice Hall.

Mr. Pandey is Assistant Professor of English at the Department of Languages and Mass Communication, Kathmandu University. 